\title{
Influence of aseptic surge tank venting on equipment sterilization
}

\section{Impacto da desaeração de tanques assépticos na esterilização do equipamento}

\author{
Marcio Scucuglia ${ }^{1 *}$ (D), Flávio Schmidt ${ }^{1}$, Alfredo Vitali ${ }^{2}$, Valquiria Ros-Polski ${ }^{3}$ \\ ${ }^{1}$ Universidade Estadual de Campinas (UNICAMP), Faculdade de Engenharia de Alimentos, Campinas/SP - Brasil \\ ${ }^{2}$ Instituto de Tecnologia de Alimentos (ITAL), Campinas/SP - Brasil \\ ${ }^{3}$ BlackBoxOpeners (BBO), Campinas/SP - Brasil
}

*Corresponding Author: Marcio Scucuglia, Universidade Estadual de Campinas (UNICAMP), Faculdade de Engenharia de Alimentos, Rua Monteiro Lobato, 80, Cidade Universitária Zeferino Vaz, CEP: 13083-862,

Campinas/SP - Brasil, e-mail: scucugliam@gmail.com

Cite as: Scucuglia, M., Schmidt, F., Vitali, A., \& Ros-Polski, V. (2019). Influence of aseptic surge tank venting on equipment sterilization. Brazilian Journal of Food Technology, 22, e2017125. https://doi.org/10.1590/19816723.12517

\begin{abstract}
Aseptic surge tank (AST) systems are applied to aseptic production in order to store sterile product until aseptic filling, maintaining the commercial sterility condition achieved from previous production steps. To avoid microbial recontamination of the product, a sterility condition must be achieved in the aseptic tank system through the application of a heating, venting, and sterilization cycle. This cycle must follow specific validation protocols to ensure operational integrity - FDA 21 CFR Part $113.40 \mathrm{~g}$ (ii). The demand for larger capacity systems and the implication of this volume increase on sterilization efficiency require a review of results obtained from current validation protocols. The purpose of this work was to evaluate aseptic surge tank's venting cycles, studying internal pressure and temperature distribution to better understand this operation and its efficiency. Tests carried out at an industrial setting showed that the venting cycle was insufficient, with $13 \%-23 \%$ of air remaining inside the tank. Consequently, the subsequent sterilization process was not conducted under saturated steam condition. This different condition may change the kinetics for thermal destruction of microorganism spores from a moist heat state to a drier state in which its thermal resistance is higher. This finding raises a question regarding the true efficacy of the sterilization process and validation protocols currently used by the industry. The apparent success of current sterilization processes could be due to the application of excessive temperature and longer times. New operational and validation criteria will result in improvements in product integrity protection and operational cost reductions.
\end{abstract}

Keywords: Aseptic surge tank; Sterilization; Venting; Validation; Heat distribution.

\section{Resumo}

Tanques assépticos (AST) são sistemas aplicados para estocagem do produto estéril até o envase, mantendo a condição de esterilidade comercial obtida nas etapas anteriores do processo. Para evitar a recontaminação microbiológica do produto, uma condição de esterilidade deve ser alcançada no tanque antes da produção, pela aplicação de um ciclo de aquecimento, desaeracão e esterilização. A demanda por sistemas de maior capacidade e a implicação deste aumento de volume na eficiência de esterilização requerem uma revisão dos resultados obtidos 
a partir de protocolos de validação atuais. O objetivo deste trabalho foi avaliar os ciclos de desaeracão de um tanque asséptico, através do estudo da pressão interna e da distribuição da temperatura em seu interior. O resultado dos testes realizados em um ambiente industrial mostrou que o ciclo de desaeracão era insuficiente, com $13 \%$ a $23 \%$ de ar restante dentro do tanque asséptico. Consequentemente, o processo de esterilização subsequente não foi conduzido sob condições de vapor saturado - o que pode mudar a cinética de destruição térmica de esporos de micro-organismos de um estado de calor úmido para um estado mais seco, no qual a sua resistência térmica é mais elevada. Esta observação pode levantar questionamentos sobre a verdadeira eficácia do processo de esterilização e dos protocolos de validação atualmente utilizados pela indústria. O sucesso aparente dos atuais processos de esterilização pode ser devido à aplicação de temperaturas e tempos excessivos. Novos critérios operacionais e de validação podem resultar em melhorias da integridade do produto e na redução de custos operacionais.

Palavras-chave: Tanque asséptico; Esterilização; Ventilação; Validação; Distribuição de calor.

\section{Introduction}

Aseptic processing is a food preservation technology in which product and package are continuously sterilized in separated events; canning (product transfer, package filling with product and container sealing) is performed in a sterile controlled environment conducted and maintained under commercial sterility condition (Chambers \& Nelson, 1993).

The aseptic process provides several benefits, like better quality and reduced nutritional losses when compared with traditional retort process, independence of refrigeration upon the end of shelf life, and versatility (Bockelmann, 1998; GEA Procomac Process Engineering, 2008). It also requires additional controls in all process steps to protect product and package from microbiological recontamination after sterilization (Burton, 1988), resulting in the need for robust automation and quality system.

Intermediate Aseptic Surge Tanks (AST) are applied in Aseptic System to allow accumulation of sterilized product, maintaining its commercial sterility as a "buffer" prior to send to the aseptic filling machine (Burton, 1988). In addition to this flexibility, this device prevents the product recirculation, reducing nutritional and quality losses.

One of the main steps of the AST's operation is the pre-sterilization, where the internal surfaces in contact with the sterile product and the filter elements that will feed the tank with sterile air/nitrogen are brought to a commercial sterility condition by heating with saturated steam.

The environment around the spores influences the efficiency of the heat sterilization process (Pflug, 1960). Moist heat destruction processes are those in which the microorganisms are subjected to thermal destruction in the presence of saturated steam or in a wet condition. On the other hand, dry heat sterilization occurs when the atmosphere has overheated steam or hot air.

Coroller et al. (2001) observed significant increase in D-value for B. cereus spores heated in different solutions of glycerol, glucose, sucrose and varying water activity values. The same effect was observed by Gombas (1993), which concluded that the spores inactivation in dry heating (aw $<0.1$, ERH $<10 \%$ ) is lower than that observed in wet heating.

Pflug (1999) reports the $\mathrm{D}_{120^{\circ} \mathrm{C}}=0.67$ minutes and z-value of $8.0^{\circ} \mathrm{C}$ for Bacillus subtilis spores, obtained in moist heat processes ( $\mathrm{aw}=1.0, \mathrm{ERH}=100 \%$ ), and 4.4 to 6.8 minutes to process under dry heat $(\mathrm{aw}<0.1$, ERH $<10 \%$ ). Similar values were observed for dry heat (Prado Filho, 1987a, 1987b, 1987c), with $\mathrm{D}_{120^{\circ} \mathrm{C}}$ around of 20 minutes for aw $=0.75(\mathrm{ERH}=75 \%)$. Smith et al. (1982) found $\mathrm{z}$-values of $42^{\circ} \mathrm{F}\left(23.3^{\circ} \mathrm{C}\right)$ for Bacillus subtilis subjected to dry heat and $\mathrm{z}=14.8^{\circ} \mathrm{F}\left(8.2^{\circ} \mathrm{C}\right)$ to moist heat, with conclusions similar to those of Pflug (1960) and Prado Filho (1987a, b, c).

To ensure AST pre-sterilization efficiency, venting procedures are used to remove air from the vessel prior to heat sterilization, following the same approach as in steam retorts. For retort systems, the venting process 
is validated by complementary heat distribution/penetration evaluation that guarantees delivery of adequate thermal process to the packaged product. Differently for aseptic tank sterilization, the venting failure may cause equipment understerilization, leading to sterile product recontamination.

The AST venting processes have been validated by remotely operated data loggers to ensure the efficiency of AST venting steps through confirmation of heat distribution inside the tank.

Considering the tendency to use larger volume tanks to attend increased line capacities, venting could become a challenge. The venting processes prior to sterilization of ASTs and the methodologies used for validation should be performed in such a way to face the phenomena that occurs inside the vessel.

The purpose of this work was to evaluate AST's venting cycles, studying internal pressure and temperature distribution, in order to better understand this operation and its efficiency according to the steps below.

1. To evaluate the current protocols for venting and sterilization of AST's validation;

2. To assess pressure and steam temperature profiles within the AST's during venting and sterilization steps;

3. To present suggestions for a new AST venting protocol.

\section{Materials and methods}

The experiments were conducted in a production plant located in Sorocaba, São Paulo State, Brazil. Two Aseptic Surge Tanks (AST) (20,000 liters) supplied by Tetra Pak (Denmark) were used in the experiments. A calibrated pressure transmitter (Endress + Hauser Cerabar M PMC/PMO 41-48; accuracy: 0.05\%) was used to measure the AST's internal pressure.

\subsection{Remote data logger programming}

A remote temperature data logger (Ellab Tracksense ${ }^{\circledR}$, Denmark) was used and the temperature sensors were calibrated with $0.05^{\circ} \mathrm{C}$ resolution. Fourteen temperature sensors had their internal clock set synchronized to the AST's PLC (Programmable Logic Controller) time. Sensors were programmed for reading every $60 \mathrm{~s}$ (tests 1 and 2) or $30 \mathrm{~s}$ (tests 3 and 4), both for $48 \mathrm{~h}$ recording. After experiments, data were downloaded and converted into Excel $\mathbb{R}$ spreadsheet format.

\subsection{Temperature data logger installation}

The 14 sensors were uniformly distributed in the AST internal wall and fixed with temperature resistant adhesive aluminum foil tape (Model: 425, 3M, Campinas, SP, Brazil). The data loggers' positions were: three heights (top, middle and bottom) and $90^{\circ}$ with respect to each AST axis. Location coordinates were defined according to a watch dial, with the steam inlet at the position equivalent to 9 o'clock.

Tables 1 and 2 describe the coordinates applied for sensor installation positions in the internal surface of the AST.

Table 1. Sensors positioning on tests 1 and 2 .

\begin{tabular}{cccc}
\hline Sensor & Position (o'clock) & Sensor & Position (o'clock) \\
\hline 1 & Top (9) & 10 & Top (3) \\
3 & Top (12) & 11 & Middle (3) \\
4 & Middle (9) & 16 & Bottom (6) \\
5 & Bottom (9) & 17 & Bottom (3) \\
8 & Middle (12) & 18 & Top (6) \\
9 & Middle (6) & 19 & Middle (6) \\
\hline
\end{tabular}


Table 2. Sensors positioning on tests 3 and 4.

\begin{tabular}{cccc}
\hline Sensor & Position (o'clock) & Sensor & Position (o'clock) \\
\hline 1 & Top (3) & 11 & Bottom (12) \\
2 & Bottom (3) & 12 & Top (12) \\
5 & Middle (3) & 13 & Top (9) \\
6 & Middle (9) & 14 & Middle (12) \\
7 & Bottom (6) & 15 & Middle (6) \\
8 & Bottom (9) & 16 & Bottom (6) \\
10 & Top (6) & 17 & Top (9) \\
\hline
\end{tabular}

\subsection{Tank sterilization cycle}

Four sterilization cycles were conducted (test 1 immediately followed by test 2 and test 3 immediately followed by test 4 ). Between tests 2 and 3, there was a 16 months interval - this time was required to accommodate project installation schedule, as trials were conducted in an industrial facility. For all tests, the same original automation logic provided with the equipment for heating, venting and sterilization was applied according to the following steps (Figure 1) shows details of the controlling points and tank design):

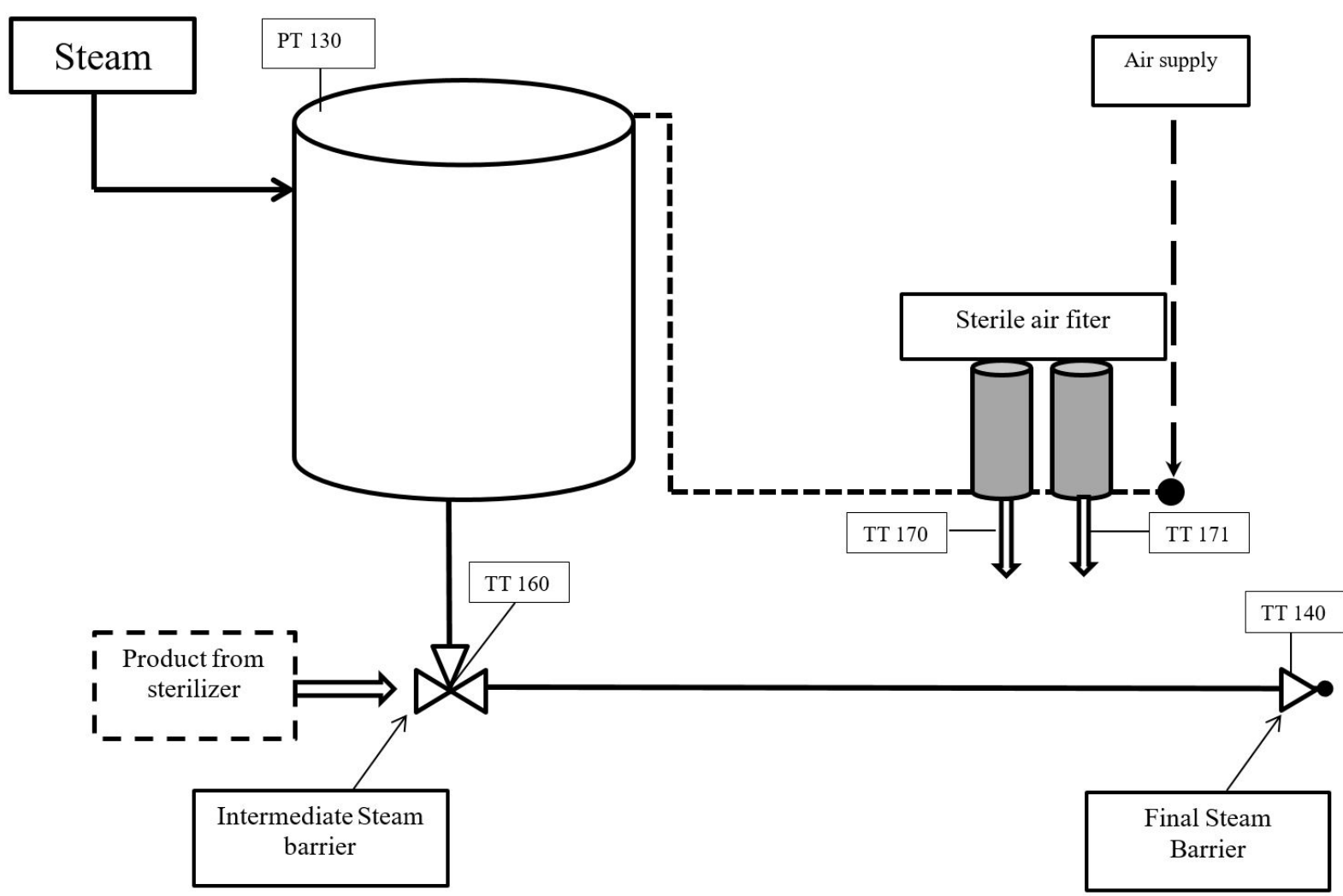

Figure 1. Basic Instrumentation Diagram of Aseptic Tank; TT = temperature transmitter; PT = pressure transmitter.

- draining of steam lines of 1.0 and 2.7 bar;

- injection of 2.7 bar saturated steam until temperature achieved $110^{\circ} \mathrm{C}$ in the steam barrier at the end of the line (TT140);

- venting until reaching the sterilization temperature of $125^{\circ} \mathrm{C}$ in TT140 and in TT 171 and TT170 (condensate collecting lines downstream of the sterile air filter);

- holding process for 30 minutes above $125^{\circ} \mathrm{C}$ TT140, TT170 and TT 171; 
- AST cooling by sterile air/nitrogen injection via sterile air filters and by room temperature water circulation in the outer jacket.

The start and end time of each step, the temperature data points and the internal tank pressure were recorded in the AST's PLC memory.

\subsection{Data analysis}

The temperature and pressure data were organized in Excel ${ }^{\circledR}$ spreadsheets. All evaluations were conducted for the pre-heating, venting and sterilization cycle steps. The cooling phase was not considered.

The temperature data from each sensor, during the isothermal sterilization phase, were averaged (average temperature - AV). The AST's slowest heating point was identified as the position of the lowest temperature at the beginning of the sterilization phase.

\subsection{Saturated steam relationship}

The saturated steam temperature of the system in equilibrium (sterilization step) was calculated by the Antoine equation (Antoine, 1888) (Equation 1) using pressure data obtained from the system PLC.

$$
\log p=A-\frac{B}{C+T}
$$

Where:

$p=$ absolute vapor pressure $(\mathrm{mmHg})$

$T=$ temperature $\left({ }^{\circ} \mathrm{C}\right)$

$A, B$ and $C$ are constants. For systems with pure water between $99{ }^{\circ} \mathrm{C}$ and $374{ }^{\circ} \mathrm{C}$, values are (Antoine, 1888; Perry, 1984):

$$
A=8.14019 ; B=1810.94 ; C=244.485
$$

\subsection{Estimation of remaining air inside the AST}

Initially, the tank partial saturated steam pressure $\left(P_{\text {Sat }}\right)$ was calculated applying the averaged temperature (AV) during the sterilization step to the Antoine Equation (Equation 1).

The difference between the measured pressure $\left(P=\mathrm{P}_{\text {Total }}\right)$ in the tank during sterilization and $P_{\text {Sat }}$ represents the partial pressure of air inside the AST sterilization $\left(P_{\text {Air }}\right)$ (Equation 2).

$P_{\text {Air }}=P-P_{\text {SatS }}$

The number of moles of air present along with the steam was calculated by applying this partial air pressure $\left(P_{\text {Air }}\right)$ in Clapeyron equation (Equation 3) (Atkins, 1995).

$n_{\text {Air }}=\frac{P_{A i r} \times V}{R \times T}$

Where:

$n_{\text {Air }}$ - air number of moles

$T$ - AV, Kelvin

$R-1.9872$, cal.gmol ${ }^{-1} \cdot \mathrm{K}^{-1}$

$V$ - AST volume, $\mathrm{m}^{3}$

$P_{\text {Air }}$ - calculated air pressure, atm

The mass of air ( $\left.m_{\text {Air }}\right)$ was calculated according to Equation 4 (Atkins, 1995; Fellows, 2006). 
$m_{\text {Air }}=n_{\text {Air }} \times M_{\text {Air }}$

Where:

$M_{\text {Air }}$ - air molar mass, $28.92 \mathrm{~g} / \mathrm{mol}$

The saturated steam mass ( $m_{\text {Steam }}$ ) (Equation 6$)$ was obtained from the product of the steam density (D) (Equation 5) (Bird et al., 1985) and the AST's volume (V, $\left.\mathrm{m}^{3}\right)$.

$D=A \times T-B$

Where:

$A=0.0439$;

$B=4.2052$;

$T=$ steam temperature, ${ }^{\circ} \mathrm{C}$

$m_{\text {Steam }}=D \cdot V$

The percentage of entrapped air $\left(\%_{A i r}\right)$ in the AST was calculated by Equation 7.

$$
\%_{\text {Air }}=100 \times \frac{m_{\text {Air }}}{m_{\text {Air }}+m_{\text {Steam }}}
$$

\section{Results and discussion}

\subsection{Evaluation of the AST venting process}

The data evaluation of all experiments resulted in curves that are similar to the one in Figure 2, obtained from sterilization Test 1 . The lines on the graphic represent:

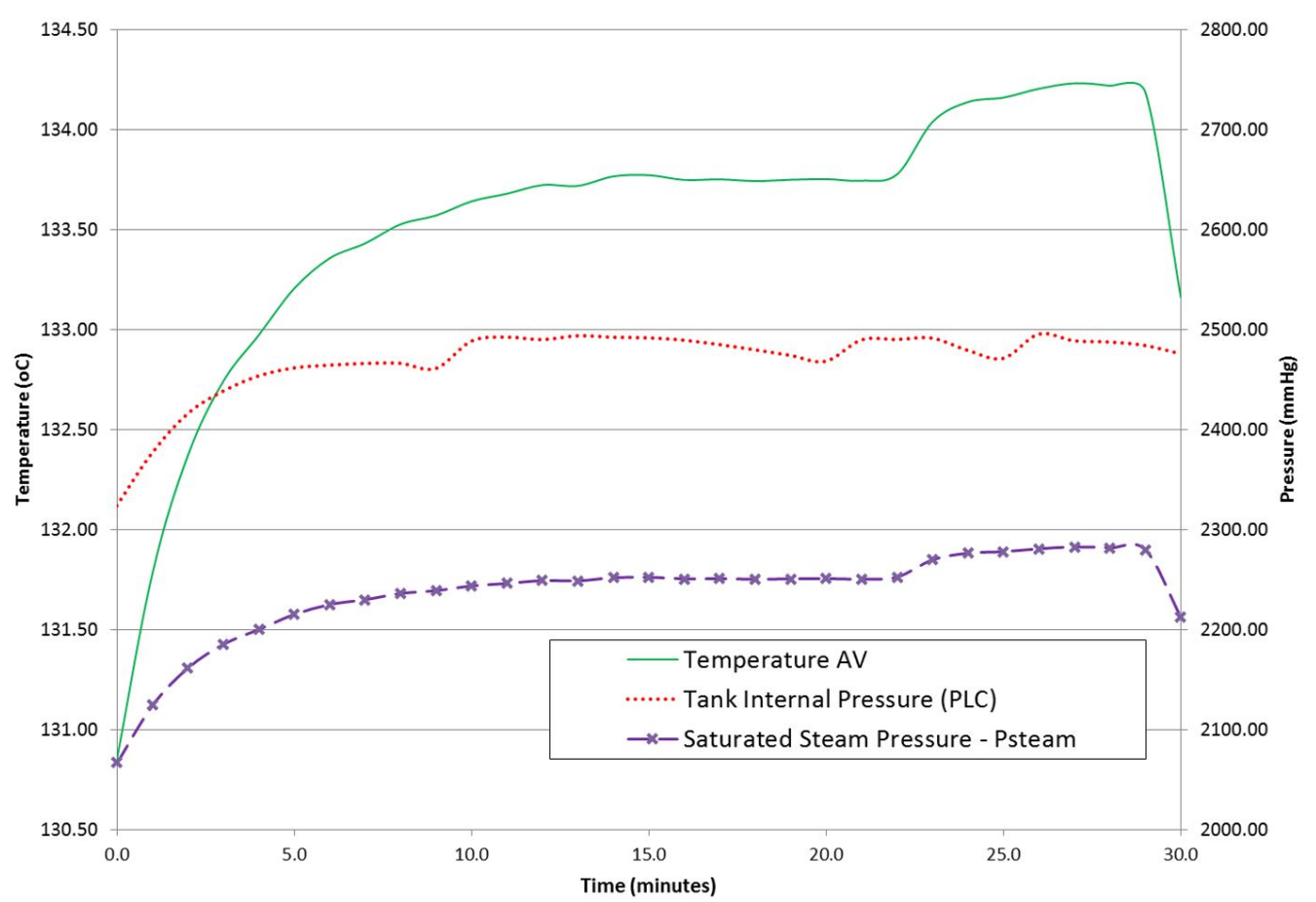

Figure 2. Data from Test \#1 Sterilization Cycle - Average temperature distribution read from sensors - Temperature AV; Absolute pressure inside the tank measured during sterilization - Tank Internal Pressure (PLC) and absolute pressure calculated by the Antoine Equation during sterilization cycle -Saturated Steam Pressure - Psteam"). 
- The average internal surface temperature of the AST obtained from the remote sensors (Temperature AV);

- The Internal Pressure of the Aseptic Tank read from PLC during the sterilization (Tank Internal Pressure PLC);

- The Saturated Steam Pressure $\left(P_{\text {Steam }}\right)$ related to the averaged measured internal temperature (AV) calculated by Antoine Equation.

The average temperatures obtained in the tank surface for all the trials are presented in Table 3.

The results on Table 3 indicated that trials 3 and 4 were very similar, but trials 1 and 2 showed a very different behavior. The difference between these trials shows that the current venting process controls can result in different temperature profiles in the tank surface. This confirms that the proposal of changing the venting success criteria could improve sterilization process.

Table 3. Average internal surface temperatures of the AST during the sterilization cycles of tests 1 to 4 .

\begin{tabular}{|c|c|c|c|c|}
\hline Trial & $\begin{array}{c}\text { Temperature }{ }^{\circ} \mathrm{C}- \\
\text { Minimum }\end{array}$ & $\begin{array}{c}\text { Temperature }{ }^{\circ} \mathrm{C}- \\
\text { Maximum }\end{array}$ & $\begin{array}{c}\text { Temperature }^{\circ} \mathrm{C}- \\
\text { Average }\end{array}$ & $\begin{array}{c}\text { Temperature } \\
\text { Standard Deviation }\end{array}$ \\
\hline 1 & 130.85 & 134.23 & 133.51 & 0.72 \\
\hline 2 & 128.54 & 131.77 & 130.81 & 0.84 \\
\hline 3 & 129.81 & 136.28 & 134.41 & 1.7 \\
\hline 4 & 129.80 & 136.46 & 134.50 & 1.67 \\
\hline
\end{tabular}

AST: Aseptic Surge Tank.

\subsection{Calculation of the amount of air remaining inside the tank during sterilization}

The calculated amount of residual air inside the aseptic tank during the sterilization cycles is presented in Table 4 . The amount of air was between 10 to $23 \%$ of the total tank volume. These results confirm that the sterilization process does not occur with pure saturated steam, but in a mixture of steam and air.

Table 4. Air content present in the AST during the sterilization cycles of tests 1 to 4.

\begin{tabular}{cccc}
\hline Trial & \% air - Minimum & \% air - Maximum & \% air - Average \\
\hline 1 & 11.57 & 16.08 & 13.87 \\
2 & 20.61 & 25.77 & 23.02 \\
3 & 10.61 & 23.89 & 15.35 \\
4 & 10.60 & 23.91 & 15.64 \\
\hline
\end{tabular}

AST: Aseptic Surge Tank.The presence of air in the steam reduces the heat transfer rates, as described by Fellows (2006), resulting in a less efficient process. This means that a higher temperature and length of time are required to reach target sterilization.

A validation of the sterilization process must be designed, conducted and reported to ensure its efficiency and repeatability (Pflug, 1999; GMA Science and Education Foundation, 2007). The pre-sterilization procedures and parameters for aseptic systems must be determined by heat distribution in the AST or through microbial challenge tests ("Challenge Test") (GMA Science and Education Foundation, 2007).

Pflug (1999) states that, for equipment surfaces, the process using saturated steam with temperatures properly recorded generates more reliable data than the use of biological indicators (spore strips).

Usually, the use of temperature loggers allows to confirm that the surface reaches the minimum temperature of $125^{\circ} \mathrm{C}$, which is kept for 30 minutes (Burton, 1988), confirming that the sterilization achieves the success criteria defined for current validation protocols (IFTPS).

On the other hand, the variation of air content, as presented in Table 3, indicates that the process show no repeatability. This leads to a conclusion that current protocols should include validation of the venting and heating steps, similar to retort systems procedures. 


\subsection{Effects on lethality due to remaining air in the AST during sterilization}

Lethality was calculated for Clostridium botulinum (Ball \& Olson, 1957; Pflug, 1999).

The results show that the sterilization of AST does not occur in a steam saturation condition. Thus, the spores' destruction by this unsaturated steam is probably less efficient than it would be in a steam saturation condition. Therefore, the use of temperature loggers according to Pflug (1960) should be revised.

When calculating the lethal rate of a thermal process at $130{ }^{\circ} \mathrm{C}$ relative to a reference temperature of $121.1^{\circ} \mathrm{C}$, it would be possible to compare the effect of different steam saturation conditions by application of the z-value obtained by Smith et al. (1982) in two different conditions. Using the z-value of $8.2^{\circ} \mathrm{C}$ (Smith et al., 1982), for $B$. subtilis under saturation condition, a lethal rate of 12.2 minutes is obtained. The same calculation, using the z-value of $23.3^{\circ} \mathrm{C}$ (Smith et al., 1982), for $B$. subtilis under dry heat condition, results in a lethal rate equal to 2.4 minutes. This means that the sterilization process conducted in the AST under "dry heat condition" could be up to 5 times less efficient than the same process conducted in the condition of steam saturation for this microorganism.

Therefore, the simple temperature reading on the surface does not evaluate the real effect of microorganism's destruction, and it is necessary to review the validation concepts and to consider alternatives approaches such as the use of bio-indicators.

The operating condition observed in the tests during sterilization - despite the steam saturation condition - is around 2.10 bar (gauge pressure) and $130^{\circ} \mathrm{C}$ for 30 minutes. The process equivalent to the dry heat lethal rate could be obtained by Equation 8 (Ball \& Olson, 1957; Pflug, 1999). Equation 8 could be simplified to Equation 9, when the lethality $\mathrm{L}$ is constant.

$(\delta \mathrm{F}=\mathrm{Ldt})$

$F=t \times L$

Where:

$F=$ thermal process equivalent time

$t=$ thermal process real time

$L=$ lethal rate for equivalent temperature

$F=30\left[\right.$ minutes at $\left.130^{\circ} \mathrm{C}\right] \times 2.40=72$ minutes at $121.1^{\circ} \mathrm{C}$

Under saturated condition, the effect of 72 minutes at $121.1^{\circ} \mathrm{C}$ would be obtained by rearranging Equation 9 and dividing 72 minutes by the lethal rate for moist heat:

$t=72[$ minutes $] / 12.17=6$ minutes at $130{ }^{\circ} \mathrm{C}$

A process of 6 minutes at saturated condition $\left(130^{\circ} \mathrm{C}\right.$ and 1.67 bar) would result in the same lethality as 30 minutes at unsaturated condition ( 2.10 bar) for $B$. subtilis. Thus, a complete venting may result in shorter sterilization processes and lower pressure, with the same lethality.

\section{Conclusions}

The evaluation of AST venting indicated the presence of residual air inside the vessel. The presence of air results in heat transfer reduction, and the sterilization process cannot occur in steam saturation condition. As consequence, the lethality obtained in the process may be lower than that expected for moist sterilization.

The apparent success of the current AST sterilization is possibly due to the high temperature applied, which has probably been considered in the partial venting design to compensate for the heat transfer reduction due to the presence of residual air. 
The high temperature applied and the volume of air trapped in the tank result in high working pressures and imply the need for robust pressure vessel designs. The trend of increasing the nominal volume of the tanks used in industry to accommodate growing demands of production results in increasing the volume of air inside the tanks considering the current procedures. This leads to a reduction of heat transfer, the need for more robust designs, and higher operating costs to maintain the necessary high sterilization temperature.

An efficient venting is obtained by an appropriated mechanical drag of residual air by steam, with no obstructions. This is achieved with a correct sizing of steam inlet and outlet pipes. In order to minimize the application of high temperature and pressure in venting and sterilization steps, it is necessary to develop new venting and validation procedures.

Processes occurring at saturation allow greater lethality and heat transfer coefficients, even at lower temperatures and pressures, allowing cost reduction and review of current pressure vessels projects.

\section{Acknowledgements}

We would like to thanks IEH for the usage of the remote sensors, and PepsiCo Brazil for the usage of equipment and resources.

\section{References}

Antoine, C. (1888). Tensions de vapeurs: nouvelle relation entre les tensions et les temperatures. Comptes Rendus des Séances de l'Académie des Sciences, 89, C681-C884.

Atkins, P. W. (1995). Physical chemistry (5th. ed., 1031 p.). New York: Oxford University Press.

Ball, C. O., \& Olson, F. C. W. (1957). Sterilization in food technology (633 p.). New York: McGraw Hill Book Company.

Bird, R. B., Stewart, W. E., \& Lightfoot, E. N. (1985). Transport phenomena (5th ed., 780 p.). Hoboken: John Willey \& Sons INC. Bockelmann, B. V. (1998). Long-life products: a guide to quality (246 p.). Värnamo: Fälth \& Hässler.

Burton, H. (1988). Ultra high temperature processing of milk and milk products (353 p.). London: Elsevier.

Chambers, J. V., \& Nelson, P. E. (1993). Principles of aseptic processing and packaging (247 p.). Washington: The Food Processor Institute.

Coroller, L., Leguerinel, I., \& Mafart, P. (2001). Effect of water activities of heating and recovering media on apparent heat resistance of Bacillus cereus spores. Applied and Environmental Microbiology, 6(1), C317-C322. http://dx.doi.org/10.1128/AEM.67.1.317-322.2001

Fellows, P. J. (2006). Tecnologia do processamento de alimentos: princípios e prática (2nd ed., 602 p.). Porto Alegre: Artmed. GEA Procomac Process Engineering. (2008). Inside aseptic (112 p.). Parma: Grapho Service.

GMA Science and Education Foundation. (2007). Canned foods: principles of thermal process control, acidification, and container closure evaluation (193 p.). Washington, D. C.: GMA SEF.

Gombas, D. E. (1993). Bacterial spore resistance to heat. Food Technology, C100-C104.

Perry, R. H. (1984). Perry's chemical engineer's handbook (5th ed.). Chicago: R. R. Donneley \& Sons Company.

Pflug, I. J. (1960). Thermal resistance of microorganism to dry heat: design of apparatus, operational problems and preliminary results. Food Technology, 14, C483-C487.

Pflug, I. J. (1999). Microbiology and engineering of sterilization process (10th ed.). Mineapolis: Enviromental Sterilization Laboratory.

Prado Filho, L. G. (1987a). Resistência térmica de Conidiosporos de Aspergillus parasiticus Speare ao vapor seco. Ciência e Tecnologia de Alimentos, 7, C50-C62.

Prado Filho, L. G. (1987b). Resistência térmica de microrganismos em ambiente de baixa atividade de água - I - Montagem de equipamento específico e cálculos termodinâmicos. Food Science and Technology, 7, C27-C49.

Prado Filho, L. G. (1987c). Resistência térmica de microrganismos em ambiente de baixa atividade de água - II Resistência de esporos de Bacillus subtilis var. niger ATTCC 9372 frente a vapor superaquecido. Ciência e Tecnologia de Alimentos, 7(2), 123144.

Smith, G. M., Kopelman, M., Jones, A., \& Pflug, I. J. (1982). Effect of environmental conditions during heating on commercial spore strip performance. Applied and Environmental Microbiology, 44(1), 12-18. PMid:7125646. 